\title{
Soil chemical properties, microbial biomass and soil enzyme dynamics on transplanted rice with organic amendments
}

Nika Beth Singh

Tamil Nadu Agricultural University

Selma Hamimed ( $\square$ salma.hamimed@fsb.rnu.tn )

Universite Mohammed Seddik Benyahia Jijel Faculte des Sciences et de la Technologie https://orcid.org/0000-0002-2649-6345

\section{Research Article}

Keywords: Microbial biomass, enzyme dynamics, soil available nutrients, organic manure, rice

Posted Date: February 17th, 2022

DOI: https://doi.org/10.21203/rs.3.rs-1320889/v1

License: (c) (i) This work is licensed under a Creative Commons Attribution 4.0 International License.

Read Full License 


\section{Abstract}

A field experiment was conducted at the farm of Tamil Nadu Agricultural University, India, during the Kharif season to study soil chemical properties, microbial biomass and soil enzyme dynamics on transplanted rice with organic amendments. Rice $\mathrm{CO}(\mathrm{R}) 48$ was used as a test variety. The experiment was laid out in randomized block design (RBD) with three replications and nine treatments, which are: T1 $-100 \% \mathrm{~N}$ through dhaincha + balance $\mathrm{P}$ and $\mathrm{K}$ through inorganic fertilizers, $\mathrm{T} 2-50 \% \mathrm{~N}$ through dhaincha + balance N, P and $\mathrm{K}$ through inorganic fertilizers, $\mathrm{T3}-100 \% \mathrm{~N}$ through vermicompost + balance $\mathrm{P}$ and $\mathrm{K}$ through inorganic fertilizers, $\mathrm{T} 4-50 \% \mathrm{~N}$ through vermicompost + balance $\mathrm{N}, \mathrm{P}$ and $\mathrm{K}$ through inorganic fertilizers, T5 -100\% NPK (150: 50: $50 \mathrm{~kg}$ ha-1) through inorganic fertilizers, T6 - 100\% NPK through inorganic fertilizers $+12.5 \mathrm{t}$ farmyard manure, T7 $-100 \%$ NPK through inorganic fertilizers +6.25 t dhaincha, T8 - 100\% NPK through inorganic fertilizers + 5 t vermicompost, and T9 - Control. The results revealed that maximum microbial population (bacteria, fungal, and actinomycetes), soil enzyme dynamics (urease, dehydrogenase, and soil phosphatase activity), soil available macronutrients (N, P, K) and micronutrients ( $\mathrm{Fe}, \mathrm{Zn}, \mathrm{Mn}$, and $\mathrm{Cu}$ ) were significantly influenced with the application of $100 \%$ of $\mathrm{N}$ through dhaincha + balance $P$ and $K$ through inorganic fertilizers followed by application of $100 \%$ NPK through inorganic fertilizers $+6.25 \mathrm{t}$ dhaincha. Most minor enzyme activity, microbial population \& soil available nutrients of rice were registered in absolute control.

\section{Introduction}

The natural ability of soil to support optimum growth and yield of crops depends not only on its physical and chemical properties but also on the intensity of biological processes. Soil microbes mediate the biochemical transformations of organic matter that underpin essential ecosystem functions, including decomposition, mineralization of plant-available nutrients, and nutrient retention. Organic production relies on these microbially-derived ecosystem functions and, thus, maybe a model system for the ecological intensification of agriculture [1]. Soil fertility, to a great extent, is controlled by different biochemical activities of the microflora, especially in the immediate surroundings of the roots and the rhizosphere, which under the influence of roots, carry a particularly dense population of microorganisms. Microorganisms can alter the degree of nutrient supply to higher plants through decomposition of organic compounds, immobilization of available nutrients, mineralization of nutrients or by promoting solubilization of fixed or insoluble mineral forms. The quantity and quality of soil organic matter and carbon and nitrogen inputs are the overriding controls on soil microbial biomass and activity. Thus, distinct organic amendments (e.g. manure, leguminous cover crops, and composted materials) can stimulate microbial biomass differently through increased labile organic matter [2].

Soil enzymes are a group of enzymes present in soil and are continuously playing an important role in maintaining soil ecology, physical and chemical properties, fertility and health. These enzymes also play a key role in biochemical functions in the overall process of organic matter decomposition in the soil system. They are important in catalyzing several vital reactions necessary for the life processes of microorganisms in soil and stabilization of soil structure, decomposition of organic wastes, organic 
matter formation and nutrient cycling and hence, play an important role in agriculture. The enzymatic activities of soil catalyze the biochemical activities performed by bacteria and thereby indicates the potential of soil to permit the basic biochemical processes necessary for maintaining soil fertility. Organic management increases overall enzyme activity [3], but activities of specific enzymes may change depending on the composition of the amendments and the relative availability of nutrients, as well as other factors, such as soil type and its unique characteristics [4]. Dehydrogenase activity estimates overall microbial activity due to its presence in all the microorganisms [5]. Phosphatase activity is related to the phosphorus cycle in soil. At the same time, higher phosphatase activity increases significantly in typical purple soil irrigated by biogas slurry in China [6]. Therefore, while studying the effect of different levels and sources of fertilization on soil fertility, attention must be focused on the activity of the microflora and enzymatic activity towards soil biological quality.

In rice (Oryza sativa) among the various practices, optimizing the use of manures and fertilizers is one of the important strategies for increasing productivity of rice. The contribution of organic manures is to be judged not only in terms of nutrient contribution, but also by their role in building up nutrient reserves in soil and increasing organic matter level of soil which ultimately improves physical, chemical and biological properties of soil. Using organic sources like farm yard manure, vermicompost, green manure combination with inorganic fertilizer deserves priority for sustained production and better on farm resource recycling and utilization. Organic manure provides nutrients, growth promoting substances, as well as they are microbial enriched products that play a vital role in organic rice production. In the present investigation, an attempt was made to examine the influence of different levels and sources of fertilization on dynamics of soil chemical properties, microbial biomass and enzyme activities under anaerobic rice cultivation.

\section{Materials And Methods}

A field experiment was conducted during kharif season at Tamil Nadu Agricultural farm, India. The initial analysis of the soil of the experimental site (Table 1) revealed that the soil was slightly alkaline $(\mathrm{pH}=$ 7.85) with low in soluble salts $\left(E C=0.42 \mathrm{dSm}^{-1}\right)$, medium in organic carbon content ( 0.58 per cent), low in available $\mathrm{N}\left(216 \mathrm{~kg} \mathrm{ha}^{-1}\right)$, medium in $\mathrm{P}_{2} \mathrm{O}_{5}\left(16.2 \mathrm{~kg} \mathrm{ha}^{-1}\right)$ and high in $\mathrm{K}_{2} \mathrm{O}\left(426 \mathrm{~kg} \mathrm{ha}^{-1}\right)$. The irrigation water was found to be neutral in reaction $(\mathrm{pH}=7.6)$ with medium level of the soluble salts $(E C=1.18$ $\left.\mathrm{dSm}{ }^{-1}\right)$.

The maximum and minimum temperature ranged from 29.0 to $32.7^{\circ} \mathrm{C}$ and 19.2 to $23.7^{\circ} \mathrm{C}$, respectively. With regard to relative humidity, there was a fluctuation from 77.5 to 94 per cent ( 0722 hours) and from 49.6 to 77.3 per cent (14 22 hours). There was a total rainfall of $110 \mathrm{~mm}$ was received in 16 rainy days. The evaporation and bright sunshine hour's day ${ }^{-1}$ ranged from 2.8 to $6.6 \mathrm{~mm}$ and 3.1 to 7.4 hours, respectively

The study was conducted with nine treatments which are $T_{1}-100 \% \mathrm{~N}$ through dhaincha + balance $\mathrm{P}$ \& $\mathrm{K}$ through inorganic fertilizers, $T_{2}-50 \% \mathrm{~N}$ through dhaincha + balance N, P \& K through inorganic 
fertilizers, $T_{3}-100 \% N$ through vermicompost + balance P \& K through inorganic fertilizers, $T_{4}-50 \% \mathrm{~N}$ through vermicompost + balance N, P \& K through inorganic fertilizers, $T_{5}-100 \%$ NPK (150:50:50 kg $\mathrm{ha}^{-1}$ ) through inorganic fertilizers, $\mathrm{T}_{6}-100 \%$ NPK through inorganic fertilizers $+12.5 \mathrm{t}$ farmyard manure, $\mathrm{T}_{7}-100 \%$ NPK through inorganic fertilizers $+6.25 \mathrm{t}$ dhaincha, $\mathrm{T}_{8}-100 \%$ NPK through inorganic fertilizers $+5 \mathrm{t}$ vermicompost, $T_{9}-$ Control. The experiment was laid out in RBD with three replications. The test crop were used is medium duration rice variety $\mathrm{CO}(\mathrm{R}) 48$.

\subsection{Soil chemical analysis}

Soil samples were taken before the start of experiment and harvest of rice for analysis. Pre-sowing composite soil sample was analysed for mechanical and chemical properties. The soil samples were collected from each plot at 0-15 cm depth, dried under shade, powdered, sieved through $2 \mathrm{~mm}$ sieve and analysed for $\mathrm{pH}, \mathrm{EC}$, organic carbon, macro, secondary and micro-nutrients following the standard procedures as shown in Table 1. 
Table 1

Soil chemical characteristics of the pre experimental field

\begin{tabular}{|c|c|c|c|}
\hline Particulars & Value & Method & Reference \\
\hline \multicolumn{4}{|l|}{ I. Chemical characteristics } \\
\hline $\mathrm{pH}$ & 7.85 & $\begin{array}{l}\text { Using glass electrode in the "ELICO" pH } \\
\text { meter }\end{array}$ & \multirow[t]{2}{*}{ [7] } \\
\hline $\begin{array}{l}\text { Electrical conductivity (dS } \\
\mathrm{m}^{-1} \text { ) }\end{array}$ & 0.42 & Using “ELICO” conductivity bridge & \\
\hline Organic carbon (\%) & 0.58 & Chromic acid wet digestion method & [8] \\
\hline Available $\mathrm{N}\left(\mathrm{kg} \mathrm{ha}^{-1}\right)$ & 216 & Alkaline permanganate method & [9] \\
\hline Available $\mathrm{P}_{2} \mathrm{O}_{5}\left(\mathrm{~kg} \mathrm{ha}^{-1}\right)$ & 16.2 & Olsen method using colorimeter & [10] \\
\hline Available $\mathrm{K}_{2} \mathrm{O}\left(\mathrm{kg} \mathrm{ha}^{-1}\right)$ & 426 & Flame photometric method & [11] \\
\hline DTPA-Fe $\left(\mathrm{mg} \mathrm{kg}^{-1}\right)$ & 27.8 & \multirow[t]{4}{*}{ Atomic Absorption Spectrophotometry } & \multirow[t]{4}{*}{ [12] } \\
\hline DTPA-Cu $\left(\mathrm{mg} \mathrm{kg}^{-1}\right)$ & 3.2 & & \\
\hline DTPA-Mn $\left(\mathrm{mg} \mathrm{kg}^{-1}\right)$ & 8.6 & & \\
\hline DTPA-Zn (mg kg-1) & 3.8 & & \\
\hline \multicolumn{4}{|c|}{ II. Irrigation water characteristics } \\
\hline $\mathrm{PH}$ & 7.6 & Potentiometry & \multirow[t]{2}{*}{ [7] } \\
\hline $\begin{array}{l}\text { Electrical conductivity (dS } \\
\mathrm{m}^{-1} \text { ) }\end{array}$ & 1.18 & Conductometry & \\
\hline
\end{tabular}

\subsection{Assessment of microbial population}

The microbial population in the soil before the start of experiment of the crop was determined. The standard serial dilution plating technique of Pramer and Schemidt [13] was adopted for the estimation of microbial population and expressed as colony forming unit (cfu) g-1 of soil. The different types of microorganisms were enumerated using differential media favouring the growth of bacteria, fungi and actinobacteria as shown in Table 2. 
Table 2.Soil biological properties of the pre experimental field

Particulars Value Method

Reference

\section{Biological properties}

Total bacteria (cfu x $10^{6}$ $\mathrm{g}^{-1}$ of soil)

18 Serial dilution method using Nutrient glucose Agar medium

Total fungi (cfu x $10^{3} \mathrm{~g}^{-1}$ of soil)

10 Serial dilution method using Martin's Rose Bengal Agar medium

Total actinobacteria

4

Serial dilution method using Kenknight's Agar medium (cfu $\times 10^{4} \mathrm{~g}^{-1}$ of soil)

\subsection{Assessment of enzyme activity}

The enzyme activity was determined at initial and postharvest stages of rice. The substrates and methods followed for enzyme assays were presented in Table 3.

Table 3

Standard methods followed for soil enzyme analysis of the pre experimental field

\begin{tabular}{|c|c|c|c|c|}
\hline Enzyme & Value & Substrate & Method & Reference \\
\hline $\begin{array}{l}\text { Dehydrogenase } \\
\left(\mu \mathrm{g} \text { of TPF released } \mathrm{g}^{-1} \text { of }\right. \\
\text { soil } 24 \mathrm{~h}^{-1} \text { ) }\end{array}$ & 8.22 & $\begin{array}{l}\text { 2,3,5-Triphenyl } \\
\text { Tetrazolium chloride }\end{array}$ & $\begin{array}{l}\text { Spectrophotometer } \\
\text { at } 485 \mathrm{~nm}\end{array}$ & [17] \\
\hline $\begin{array}{l}\text { Urease } \\
\left(\mu \mathrm{g} \mathrm{NH} 4^{+} \mathrm{g}^{-1} \text { of soil } 24\right. \\
\left.\mathrm{h}^{-1}\right)\end{array}$ & 27.68 & $\begin{array}{l}10 \text { per cent urea } \\
\text { solution }\end{array}$ & $\begin{array}{l}\text { Spectrophotometer } \\
\text { at } 630 \mathrm{~nm}\end{array}$ & [18] \\
\hline $\begin{array}{l}\text { Phosphatase ( } \mu \mathrm{g} \text { of } \\
\mathrm{p} \text {-nitrophenol released } \mathrm{g}^{-1} \\
\text { of soil } \mathrm{h}^{-1} \text { ) }\end{array}$ & 12.02 & $\begin{array}{l}\text { p-nitrophenol } \\
\text { phosphate }\end{array}$ & $\begin{array}{l}\text { Spectrophotometer } \\
\text { at } 420 \mathrm{~nm}\end{array}$ & [19] \\
\hline
\end{tabular}

\section{Results And Discussion \\ 3.1. Soil chemical analysis}

Results on soil chemical analysis were presented in Table 4. Soil available nitrogen, phosphorus and potassium status was also influenced owing to the INM practice, recommended NPK fertilizers and 
different organic manures application.

\subsection{Soil available nitrogen}

The maximum soil available $\mathrm{N}\left(255 \mathrm{~kg} \mathrm{ha}^{-1}\right)$ was observed with application $100 \%$ NPK through inorganic fertilizers $+6.25 \mathrm{t}$ dhaincha which was comparable with $100 \%$ NPK through inorganic fertilizers $+5 \mathrm{t}$ vermicompost and $100 \%$ NPK through inorganic fertilizers + 12.5t FYM. Among the other treatments, higher soil available $\mathrm{N}\left(233 \mathrm{~kg} \mathrm{ha}^{-1}\right)$ was attained with $100 \% \mathrm{~N}$ through dhaincha + balance $\mathrm{P}$ and $\mathrm{K}$ through inorganic fertilizers (Table 4). This might be due to lower amount of residual nutrient in inorganic fertilizer applied field. Inorganic fertilizers cause immediate release of nutrients, which will be utilized by the crop or might have lost the environment through leaching or identification process. Higher $\mathrm{N}$ availability in the organic manures such as vermicompost, FYM might be due to higher $\mathrm{N}$ content and continuous and slow release of nutrients from organic manure and increased biomass and accumulated soil organic matter. Similar findings were also reported by Amanullah [20].

\subsection{Soil available phosphorus}

The soil available $P$ status was also improved by the addition of organic and inorganic sources of nutrient management practices (Table 4). Higher soil available $\mathrm{P}\left(18.5 \mathrm{~kg} \mathrm{ha}^{-1}\right)$ was attained with $100 \%$ NPK through inorganic fertilizers $+6.25 t$ dhaincha which was comparable with $100 \%$ NPK through inorganic fertilizers $+5 t$ vermicompost (18.2) and 100\% NPK through inorganic fertilizers $+12.5 \mathrm{t} \mathrm{FYM}$ (17.8). Among the other treatments, $100 \% \mathrm{~N}$ through dhaincha + balance $\mathrm{P}$ and $\mathrm{K}$ through inorganic fertilizers recorded the maximum soil available $\mathrm{P}\left(16.1 \mathrm{~kg} \mathrm{ha}^{-1}\right)$ compared to control. This might be due to the fact that during the mineralization of enriched organics, a number of organic acids, especially the hydroxyl ions (product of microbial metabolism) are produced, which might have released $\mathrm{P}$ through chelation or by removal of metal ions from the insoluble metal phosphates as observed by Mohandas and Appavu [21]. The influence of organic manure in increasing the label $P$ through complexing of cations like $\mathrm{Ca}^{2+}$ and $\mathrm{Mg}^{2+}$ responsible for $\mathrm{P}$ fixation has been reported by Balaguravaiah [22]. Rock phosphate enriched manures maintained higher levels of $P$ in soil solution for a longer period than the inorganic fertilizer. Higher soil available $\mathrm{P}$ could be attributed to decomposition of organic manures in the production of organic acids which in turn stabilize native insoluble $\mathrm{P}$ and led to available for longer period. Further, the higher quantity of crop residues might also have contributed $\mathrm{P}$ to the soil [23].

\subsection{Soil available potassium}

The impact of organic and inorganic sources of nutrient management practices on residual soil $\mathrm{K}$ was significant (Table 4). Application of $100 \%$ NPK through inorganic fertilizers $+6.25 t$ dhaincha registered higher soil available $\mathrm{K}\left(432 \mathrm{~kg} \mathrm{ha}^{-1}\right)$ and was comparable with $100 \%$ NPK through inorganic fertilizers + 5t vermicompost and 100\% NPK through inorganic fertilizers + $12.5 \mathrm{t} \mathrm{FYM.} \mathrm{Among} \mathrm{the} \mathrm{other} \mathrm{treatments,}$ significantly higher soil available $\mathrm{K}\left(406 \mathrm{~kg} \mathrm{ha}^{-1}\right)$ was attained with $100 \% \mathrm{~N}$ through dhaincha + balance $P$ and $K$ through inorganic fertilizers. The enhanced $K$ availability irrespective of the season coupled with higher $\mathrm{K}$ uptake due to organic manure incorporation could be attributed to higher DMP and K absorption, 
evidencing the priming effect of $\mathrm{K}$ contribution by organic manure [24]. Among the organic manures, Sesbania aculeata played a vital role in improving the uptake of NPK. This might be due to the fact that quick release of $\mathrm{N}$ from the added green manure with increased availability of $\mathrm{P}$ through the mechanism of reduction, chelation and favourable changes in soil $\mathrm{pH}$ and $\mathrm{K}$ through the priming effect and besides the direct contribution of $\mathrm{K}$ by green manure [25]. Higher $\mathrm{K}$ uptake in rice might be due to the increase in available $\mathrm{K}$, which might have contributed to mineralization of organic manures or solubilization of nutrients from native sources during decomposition [26].

Table 4

Effect of integrated nutrient management on soil available macro nutrients $\left(\mathrm{kg} \mathrm{ha}^{-1}\right)$ at harvest stage of rice

\begin{tabular}{|llll|}
\hline Treatments & Nitrogen & Phosphorous & Potassium \\
\hline $\mathrm{T}_{1}$ & 233 & 16.1 & 406 \\
\hline $\mathrm{T}_{2}$ & 211 & 14.1 & 381 \\
\hline $\mathrm{T}_{3}$ & 212 & 14.4 & 381 \\
\hline $\mathrm{T}_{4}$ & 211 & 13.9 & 380 \\
\hline $\mathrm{T}_{5}$ & 210 & 13.5 & 380 \\
\hline $\mathrm{T}_{6}$ & 254 & 17.8 & 431 \\
\hline $\mathrm{T}_{7}$ & 255 & 18.5 & 432 \\
\hline $\mathrm{T}_{8}$ & 254 & 18.2 & 431 \\
\hline $\mathrm{T}_{9}$ & 189 & 11.7 & 345 \\
\hline SEd & $\mathbf{9}$ & $\mathbf{0 . 7}$ & $\mathbf{1 1}$ \\
\hline CD (P=0.05) & $\mathbf{1 9}$ & $\mathbf{1 . 4}$ & $\mathbf{2 4}$ \\
\hline
\end{tabular}

\subsection{Soil available micronutrients}

The available soil micronutrients like Iron (Fe), Manganes (Mn), Zinc ( $\mathrm{Zn})$ and Copper $(\mathrm{Cu})$ status were presented in Table 5. Application of 100\% NPK through inorganic fertilizers $+6.25 t$ dhaincha observed that maximum uptake of Fe (2582 $\left.\mathrm{g} \mathrm{ha}^{-1}\right), \mathrm{Mn}\left(3639 \mathrm{~g} \mathrm{ha}^{-1}\right), \mathrm{Zn}\left(380 \mathrm{~g} \mathrm{ha}^{-1}\right)$ and Cu $\left(89.4 \mathrm{~g} \mathrm{ha}^{-1}\right)$ and it was followed by 100 per cent RDN through green manure and the lowest soil available micronutrients reported with absolute control. Among the other treatments, $100 \%$ NPK through inorganic fertilizers $+5 t$ vermicompost and 100\% NPK through inorganic fertilizers + 12.5 t FYM which were comparable with each other. Addition of organic materials might have enhanced the microbial activity in the soil and the 
consequent release of complex organic substances (Chelating agents) could have prevented micronutrients from precipitation, fixation, oxidation and leaching and also addition of these nutrients through organic sources. Suvarna Latha and Sankara Rao [27] stated that organic manure increased the available $\mathrm{Fe}, \mathrm{Mn}, \mathrm{Zn}$ and Cu gradually from tillering to harvest stage.

Table 5

Effect of integrated nutrient management on soil available micro nutrients $\left(\mathrm{g} \mathrm{ha}^{-1}\right)$ at harvest stage of rice

\begin{tabular}{|lllll|}
\hline Treatments & $\mathbf{Z n}$ & $\mathrm{Cu}$ & $\mathrm{Fe}$ & $\mathrm{Mn}$ \\
\hline $\mathrm{T}_{1}$ & 345 & 80.2 & 2338 & 3297 \\
\hline $\mathrm{T}_{2}$ & 280 & 64.6 & 1776 & 2895 \\
\hline $\mathrm{T}_{3}$ & 299 & 71.6 & 2007 & 2972 \\
\hline $\mathrm{T}_{4}$ & 273 & 61.4 & 1990 & 2506 \\
\hline $\mathrm{T}_{5}$ & 264 & 59.8 & 1637 & 2311 \\
\hline $\mathrm{T}_{6}$ & 313 & 72.4 & 2116 & 2985 \\
\hline $\mathrm{T}_{7}$ & 380 & 89.4 & 2582 & 3639 \\
\hline $\mathrm{T}_{8}$ & 317 & 73.8 & 2152 & 2972 \\
\hline $\mathrm{T}_{9}$ & 199 & 52.4 & 1500 & 2118 \\
\hline SEd & $\mathbf{2 2}$ & $\mathbf{6 . 1}$ & $\mathbf{1 8 0}$ & $\mathbf{2 5 2}$ \\
\hline $\mathrm{CD}(\mathbf{p}=\mathbf{0 . 0 5 )}$ & $\mathbf{4 6}$ & $\mathbf{1 2 . 4}$ & $\mathbf{3 7 8}$ & $\mathbf{5 2 8}$ \\
\hline
\end{tabular}

\subsection{Soil microbial population}

The INM practice, organic manures and recommended NPK fertilizers had influenced bacterial, fungal and actinobacterial population at postharvest stage of the crop (Table 6). 100 per cent $\mathrm{N}$ through dhaincha + balance $\mathrm{P}$ and $\mathrm{K}$ through inorganic fertilizers was recorded higher bacterial population $(40.4 \mathrm{x}$ $10^{6} \mathrm{CFU} \mathrm{g}^{-1}$ of dry soil ), fungal population $\left(17.5 \times 10^{3} \mathrm{CFU} \mathrm{g}^{-1}\right.$ of dry soil), actinobacterial population $\left(13.9 \times 10^{4} \mathrm{CFU} \mathrm{g}^{-1}\right.$ of dry soil) which was followed by $100 \%$ NPK through inorganic fertilizers $+6.25 \mathrm{t}$ dhaincha.

Among the other treatments, highest microbial population were registered with application of $100 \%$ NPK through inorganic fertilizers $+5 \mathrm{t}$ vermicompost and it was on par with $100 \%$ NPK through inorganic fertilizers + 12.5 t FYM. The lowest microbial population (fungi, bacteria and actinobacterial) was 
recorded with absolute control. In the present study, the activity of soil microbial population was increased due to the application of organic manures and green manure with the advancement of crop growth. It could be due to enhanced organic carbon content of the soil as a result of organic manure application as compared to inorganic fertilizers [27]. Lower soil microbial load found in recommended NPK fertilizers might be due to inhibitory nature of chemical fertilizers on the growth and development of microbes [28].

Table 6

Effect of integrated nutrient management on soil microbial population at harvest stage of rice

\begin{tabular}{|llll|}
\hline Treatments & Bacterial population & Fungal population & Actinobacterial population \\
\hline $\mathrm{T}_{1}$ & 40.4 & 17.5 & $\left(\times 10^{4} \mathrm{CFU} \mathrm{g}^{-1}\right)$ \\
\hline $\mathrm{T}_{2}$ & 37.1 & 14.3 & 13.9 \\
\hline $\mathrm{T}_{3}$ & 37.4 & 13.9 & 11.3 \\
\hline $\mathrm{T}_{4}$ & 36.5 & 15.6 & 12.5 \\
\hline $\mathrm{T}_{5}$ & 29.4 & 13.4 & 11.2 \\
\hline $\mathrm{T}_{6}$ & 37.8 & 15.9 & 10.8 \\
\hline $\mathrm{T}_{7}$ & 39.5 & 16.5 & 12.9 \\
\hline $\mathrm{T}_{8}$ & 38.8 & 16.1 & 13.6 \\
\hline $\mathrm{T}_{9}$ & 23.2 & 9.5 & 13.1 \\
\hline $\mathrm{SEd}$ & 3.4 & $\mathbf{1 . 3}$ & 6.2 \\
\hline $\mathrm{CD}(\mathbf{p}=\mathbf{0 . 0 5 )}$ & $\mathbf{7 . 2}$ & $\mathbf{2 . 8}$ & $\mathbf{1 . 1}$ \\
\hline
\end{tabular}

\subsection{Soil enzyme activity}

The soil enzyme activity was influenced by the INM practice, organic manures and recommended NPK fertilizers application in (Table 7).

Higher urease activity $\left(46.8 \mu \mathrm{g} \mathrm{NH}^{+} \mathrm{g}^{-1}\right.$ soil $\left.24 \mathrm{~h}^{-1}\right)$, soil dehydrogenase activity ( $36.8 \mu \mathrm{g}$ of TPF released $\mathrm{g}^{-1}$ of soil $\left.24 \mathrm{~h}^{-1}\right)$, soil phosphatase activity $\left(38.8 \mu \mathrm{g}\right.$ of $\mathrm{p}$ - nitrophenol released $\mathrm{g}^{-1}$ of soil $\left.24 \mathrm{~h}^{-1}\right)$ were observed with 100 per cent $\mathrm{N}$ through dhaincha + balance $\mathrm{P}$ and $\mathrm{K}$ through inorganic fertilizers followed by $100 \%$ NPK through inorganic fertilizers $+6.25 \mathrm{t}$ dhaincha. The lowest soil enzyme activities (urease 
activity @ $29.2 \mu \mathrm{g} \mathrm{NH}^{+} \mathrm{g}^{-1}$ soil $24 \mathrm{~h}^{-1}$, soil dehydrogenase activity @ $20 \mu \mathrm{g}$ of TPF released $\mathrm{g}^{-1}$ of soil 24 $\mathrm{h}^{-1}$, soil phosphatase activity @ $22.4 \mu \mathrm{g}$ of $\mathrm{p}$ - nitrophenol released $\mathrm{g}^{-1}$ of soil $24 \mathrm{~h}^{-1}$ ) were registered with absolute control. The organic manures particularly sesbania aculatae improves the soil unease and dehydrogenase activities and which might have improved improves soil phosphatase activities too. High organic carbon content in soil applied with dhaincha stimulated the soil microorganisms by serving as source of carbon, energy and other nutrients essential for their growth and multiplication and the increased the soil activities [4]. Higher phosphatase activity was observed with enriched organic manures treated with rock phosphate [5].

Table 7

Effect of integrated nutrient management on soil enzyme activity at harvest stage of rice

\begin{tabular}{|llll|}
\hline Treatments & Urease & Dehydrogenase & Phosphatase \\
\hline $\mathrm{T}_{1}$ & 46.3 & 36.3 & 38.3 \\
\hline $\mathrm{T}_{2}$ & 39.1 & 28.1 & 32.0 \\
\hline $\mathrm{T}_{3}$ & 40.5 & 30.5 & 32.5 \\
\hline $\mathrm{T}_{4}$ & 37.5 & 26.9 & 30.1 \\
\hline $\mathrm{T}_{5}$ & 36.0 & 24.8 & 26.9 \\
\hline $\mathrm{T}_{6}$ & 41.7 & 32.9 & 32.4 \\
\hline $\mathrm{T}_{7}$ & 45.4 & 35.6 & 36.9 \\
\hline $\mathrm{T}_{8}$ & 43.2 & 34.7 & 35.7 \\
\hline $\mathrm{T}_{9}$ & 29.2 & 20.0 & 22.4 \\
\hline $\mathrm{SEd}$ & 3.6 & $\mathbf{2 . 8 1}$ & $\mathbf{3 . 1}$ \\
\hline $\mathrm{CD}(\mathrm{P}=\mathbf{0 . 0 5 )}$ & $\mathbf{7 . 9}$ & $\mathbf{5 . 9 8}$ & $\mathbf{6 . 4 2}$ \\
\hline
\end{tabular}

1. Urease $\left(\mu \mathrm{g} \mathrm{NH}{ }_{4}^{+} \mathrm{g}^{-1}\right.$ of soil $\left.24 \mathrm{~h}^{-1}\right)$

2. Dehydrogenase ( $\mu \mathrm{g}$ of TPF released $\mathrm{g}^{-1}$ of soil $24 \mathrm{~h}^{-1}$ )

3. Phosphatase ( $\mu \mathrm{g}$ of $\mathrm{p}$-nitrophenol released $\mathrm{g}^{-1}$ of soil $24 \mathrm{~h}^{-1}$ )

\section{Conclusion}

Based on the results, it can be concluded that higher microbial population (bacteria, fungal \& actinomycetes), soil enzyme dynamics (urease, dehydrogenase \& soil phosphatase activity), soil 
available macro nutrients ( $\mathrm{N}, \mathrm{P}, \mathrm{K})$ \& micro nutrients $(\mathrm{Fe}, \mathrm{Zn}, \mathrm{Mn}, \mathrm{Cu})$ were significantly influenced with application of $100 \% \mathrm{~N}$ through dhaincha + balance $\mathrm{P} \& \mathrm{~K}$ through inorganic fertilizers followed by application of $100 \%$ NPK through inorganic fertilizers $+6.25 \mathrm{t}$ dhaincha. These integrated nutrient management practices seem to be better option for western zone of Tamil Nadu rice farmers.

\section{Declarations}

\section{Author contributions statement}

Nika Beth Singh: Collecting data and writing; Selma Hamimed: Data research, reviewing, editing and approving the paper.

\section{Acknowledgments}

This work was supported by the Tamil Nadu Agricultural farm, India.

\section{Competing interests}

The authors report that they have no conflict of interests.

\section{References}

1. Jackson LE, Bowles TM, Hodson AK, Lazcano C (2012) Soil microbial- root and microbial rhizosphere processes to increase nitrogen availability and retentionin agroecosystems.Curr. Opin. Environ. Sustain., 4,517-522

2. Kallenbach C, Grandy AS (2011) Control over soil microbial biomass responses to carbon amendments in agricultural systems: A meta-analysis. Agric Ecosyst Environ 144:241-252

3. Moeskops B, Buchan D, Sleutel S, Herawaty L, Husen E, Saraswati R, Setyorini D, De Neve S (2010) Soil microbial communities and activities under intensive organic and conventional vegetable farming in West Java. Indonesia Appl Soil Ecol 45:112-120

4. Stursova M, Baldrian P (2010) Effects of soil properties and management on the activity of soil organic matter transforming enzymes and the quantification of soil-bound and free activity. Plant Soil 338:99-110

5. Taylor JP, Wilson B, Mills MS, Burns RG (2002) Comparison of microbial number and enzymatic activities in surface soils and subsoil using various techniques. Soil Biol Biochem 34:387-401

6. Shiling C, Weiwei Y, Zhi Z, Surong L (2015) Soil properties and enzyme activities as affected by biogas slurry irrigation in Three Gorges Reservoir areas of China. J Environ Biol 36:513-520

7. Jackson ML (1973) Soil Chemical Analysis. Prentice Hall of India Pvt. Ltd., New Delhi

8. Walkley A, Black CA (1934) An examination of the Degtjareff method for determining soil organic matter and a proposed modification of the chromic acid titration method. Soil Sci 40:233-243 
9. Subbiah BV, Asija GL (1956) A rapid procedure for estimation of available nitrogen in soils. Curr Sci 25:259-260

10. Olsen SR, Cole CV, Watanabe FS, Dean AL (1954) Estimation of available phosphorus in soils by extraction on with Sodium bicarbonate Circular no: 939, USDA

11. Stanford G, English L (1949) Use of flame photometer in rapid soil test for K and Ca. Agron. J:44641

12. Lindsay WL, Norvell WA (1978) Development of DTPA soil test for Zinc, Iron, manganese and Copper. Soil Sci. Soc. Am. J., 42: 421-428

13. Pramer D, Schemidt EL (1965) Experimental Soil Microbiology. Burges Publishing Co. Minneopolis, Minnesota, $\mathrm{p} 107$

14. Collings CH, Lyne MP (1968) Microbiological Methods. 5th Edition, Butter Worth, London

15. Martin JP (1950) Use of acid, rose Bengal and streptomycin in the plate method for estimating soil fungi. Soil Sci 69:215-233

16. Kenknight G, Muncie JH (1939) Isolation of phytopathogenic actinomycetes. Phytopathlogy 29:1000-1001

17. Casida LE, Klein, Santoro T (1964) Soil dehydrogenase activity Soil Sci 98:371-376

18. Tabatabai MA, Bremner JM (1969) Use of P-nitrophenyl phosphate for assay of soil phosphatase activity. Soil Biol Biochem 1:301-307

19. Halstead RL (1964) Phosphatase activity of soils as influenced by lime and other treatments. Can J Soil Sci 44:137-144

20. Amanullah MM, Yassin MM, Somasundaram E, Vaiyapuri K, Sathyamoorthi K, Pazhanivelan S (2006b) N availability in fresh and composted poultry manure. Res J Agric Biol Sci 2(6):406-409

21. Mohandas S, Appavu K (2000) Direct and residual effect of combined application of basic slag with green leaf manures on soil available nutrients and yield of rice. Madras Agric J 87(1-3):53-56

22. Balaguravaiah D, Adinarayana G, Prathap S, Yellamanda Reddy T (2005) Influence of long-term use of inorganic and organic manures on soil fertility and sustainable productivity of rainfed groudnut in alfisols. J Indian Soc Soil Sci 53(4):606-611

23. Pazhanivelan $S$, Amanullah MM, Vaiyapuri K, Sharmila Rahale C, Sathyamoorthi K, Alagesan $A$ (2006) Effect of rock phosphate incubated with FYM on nutrient uptake and yield of lowland rice. Res J Agric Biol Sci 2(6):365-368

24. Shobarani N, Prasad GSV, Prasad ASR, Sailaja B, Muthuraman P, Numeera S and B.C. Viraktamath. 2010. Rice Almanac India. Technical Bulletin No 5, DRR, Rajendranagar, Hyderabad. pp: 6-7

25. Geethalakshmi V (1996) Studies on the direct and residual effect of non-conventional green leaf manures, with $\mathrm{N}$ for rice-rice cropping system. Ph.D. Thesis, Tamil Nadu Agric. Univ., Coimbatore

26. Suvarna Latha AJL, Sankara Rao VR (2001) Integrated use of fertilizers and poultry manure on nutrient availability and yield of rice. J. Indian Soc. Coastal Agric. Res., 19(1\&2): 153-157

27. Krishnakumar S, Saravanan A, Rajesh V, Mayil Samy P (2007) Impact of organic farming on biological properties of rice (Oryza sativa) grown soil. J Ecobiol 20(3):275-280 
28. Singh. YV, Singh KK, Sharma SK (2012) Influence of crop nutrition and rice varieties under two systems of cultivation on grain quality, yield and water use. Rice Sci 19(4):1-10 